\title{
A Survey of Effective Classroom Questioning in College English Teaching
}

\author{
Le Zhang \\ Shanxi Normal University, Linfen, China
}

\begin{abstract}
Classroom questioning is an effective teaching strategy. Questioning in classroom is not only an important source for students inputting language, but also a contributing factor for students outputting language. It plays a critical role in promoting the communication and interaction between teachers and students. Whether the class teaching is effective or not, mainly depends on questioning. Therefore, effective questioning can stimulate students' interest and motive their enthusiasm in study and then to achieve better teaching effect. More and more attention is paid to the classroom questioning home and abroad, but there is a lack of attention given to the classroom questioning in college. On the basis of the previous achievements, the author makes a survey on the freshman majoring in English in Shanxi Normal University. And through the analysis of the situation in college classroom questioning, the author tries to discuss the existing problems and put forward some improvement suggestions. The research will help teachers to find their problems in questioning and improve their questioning skills and then to promote the English teaching.
\end{abstract}

Index Terms - questioning situation, effective classroom questioning, College English class teaching

\section{INTRODUCTION}

\section{A. Background of the Study}

Since the new reform of curricula, the traditional roles of teachers and students have gradually been changing, as well as the traditional models of teaching and studying. The new curricula are trying to develop students' spirit of active learning and exploration. Besides, it cares more about the ways to acquire knowledge and development of thinking ability instead of focusing more on the quantity of the transmission of knowledge. Therefore, teachers should act as the promoters and decision makers. In order to achieve this goal, we should pay more attention to the effectiveness of class teaching. Whether class teaching is effective or not largely depends on classroom questioning. In recent years, more and more attention is paid to the classroom questioning. For example, Wu (2011), Zheng (2009) and many other scholars' researches analyze the existing problems in classroom questioning. They mainly analyze from the four aspects: the type of question, the distribution of question, the wait-time and the teacher's feedback. Through the study of the most scholars at home and abroad, the author finds that the most of the studies are in the theoretical stage, but they are not applied to the practice. And there is lack of attention given to the classroom questioning in college. So it is necessary for us to investigate the current situation in college English classroom questioning so as to improve the teaching effect. The effectiveness of questioning has a direct influence on the teaching effect and the development of learners' thinking ability.

\section{B. Purpose and Significance of the Study}

Questioning can be used as a kind of classroom interaction for teachers and students to communicate and intercourse and then to promote the English teaching. However, due to the pressure from exam-oriented education, teachers and students all make great efforts to get high scores. So under the stress, teachers often ask many informational questions to help students remember knowledge. And some teachers are unaware of the problems in the type of the questions, the distribution of question, the wait-time and the teacher's feedback.

The aim of the study is to make teachers and students aware of the existing problems in college English classroom questioning by analyzing the current situation in college English classroom questioning. And meanwhile English teachers should try their best to ask questions effectively to stimulate students' interest in English learning and active thinking dependently, thus can improve the learning and teaching effectiveness, and finally can promote students' full and healthy development.

\section{LITERATURE REVIEW}

\section{A. The Definition of Effective Classroom Questioning}

Questioning is a kind of signal stimulus and it can cause students' reaction. Class questioning refers to teaching indication or a stimulus about what has been studied by students or a direction on what to do and how to do thing.

Effective classroom questioning is a process where teachers use appropriate language to raise proper questions in teaching, and provide reasonable feedback according to students' answers, so that students can acquire knowledge and 
thus teachers achieve comprehensive teaching goals, under the guidance of specific teaching objectives or tasks. From the concept of effective classroom questioning, we can see that classroom questioning is not simple questioning and answering, but is a process of students' self-discovery and self-learning under the guidance of teachers according to certain teaching objectives.

\section{B. Classification of Questions}

Different people have different ideas on the classification of questions. For instance, Nuttal (2003) divides questions into four types based on the form of questions: yes / no questions, alternative questions, wh-questions and how / why questions. In these four questions, yes / no questions are the easiest. Students only need a simple judgment with yes or no and need not answer in complete sentences. How or why questions require students to answer in complete sentences, and students must have necessary language skills and thinking ability to make a good answer after careful thinking; Long \& Sato (1983) pays more attention to discussing referential questions and display questions.

\section{The Function of Effective Classroom Questioning}

In the article Class teaching use written by Xu Guanghou, the author summarizes seven purposes and functions of classroom questioning. (1) check what students have learned so that former knowledge can be reviewed and new knowledge can be introduced; (2) attract students' attention and cause their curiosity and interest; (3) help students participate in class actively and activate class atmosphere; (4) open students' thought and inspire their thinking so that students' intelligence and ability can be developed; (5) encourage students to speak English and promote the interaction between teachers and students; (6) It's good to embody teachers' leading role and students function as a main part of class; (7) teachers can gain feedback information and make some adjustment in teaching to make the class teaching more oriented.

\section{Previous Researches on Effective Classroom Questioning}

In the west, Socratic "Midwife" is the origin of the study of classroom questioning, Socrates was good at asking some questions to let students think independently and then acquire knowledge. With time going on, more and more well-known scholars pay attention to the classroom questioning. In summary, the studies mainly focus on the classification, the function and the strategy of classroom questioning etc. For example, in the aspect of classification, Tsui (1992) divided questions into three types: yes/no question, alternative question and wh-/how question. In the aspect of function, American scholar L.H and L.S (1985) believe that there are 19 functions of classroom questioning. In the aspect of the strategy, Norton (1989), Orstein (1995) etc. researchers put forward some effective suggestions.

In China, classroom questioning was proposed 2000 years ago. The most popular is elicitation teaching theory which put forward by Confucius. He thought the class is not only the transmission of knowledge, but the development of thinking ability. Zhu Xi also believed that learners should be active in learning rather than be a passive receiver of the knowledge. Many native scholars make great achievement in the classification, the function, the strategy of question etc. In the aspect of the classification, $\mathrm{Hu}$ (2004) expound the issue in Foreign language world, and emphasize the display question and referential question. In the aspect of function, Gao (2001) concluded six functions. In the aspect of strategy, Shi (2000) advised that questions should be clear and the wait-time should be 3-5 seconds etc.

\section{THEORETICAL FRAMEWORK}

\section{A. Stimulus-response Learning Theory}

Stimulus-Response learning theory, also called behaviorism theory, is one of the most important schools of learning theory. American psychologist Skinner believes that the cause of study is the response of external stimuli. It stimulates people's thoughts and ideas and then produces certain response. This phenomenon can be represented by S-R formula. Skinner also emphasizes reinforcement. Stimulus-Response learning theory plays an important role in studying. In class, teachers' question is a stimulus to students, and triggers a response through external stimuli, that is students' answer to the question. In the process, teachers lead students to think actively.

\section{B. Constructivist Theory}

The constructivist theory believes that learning is a process in which the learner constructs meaning and acquires knowledge based on his or her own experience. It is believed that education is used to develop the mind, not just to recall what is learned. The important representative of constructivism is Piaget. Piaget believes that individuals are born actively constructing personal meaning from their own experience. According to constructivism, students build up their own knowledge structure in the process of their learning rather than acquire knowledge directly from the teachers. In the process, students should be active rather than be a passive receiver of the knowledge. The constructivism learning theory concludes four key factors: situation, cooperation, communication, meaning construction. And the classroom questioning is the bond of the four factors, which is indispensible. It stimulates students' interest in learning English and encourages them to think actively.

\section{Methodology}




\section{A. Objects}

The study aims to figure out the existing problems in classroom questioning in college English class by analyzing the current situation of classroom questioning and put forward effective questioning suggestions to improve teachers' questioning skills, thus can cultivate students' thinking ability and promote English teaching. More specifically, there are two research questions: (1) What are the problems of classroom questioning in college English Class? (2) What teachers should do to achieve the effective classroom questioning?

\section{B. Subjects}

The author chooses 6English teachers and 4 classes in the freshman year in Shanxi Normal University as the research subjects. The average size of each class varies from 45 to 55 students, whose ages range from 18 to 20 years old. All of them have learned English since Grade 3 of elementary school and most of them have already learned English for 9 years, so they were regarded as intermediate English learners. The six teachers both have more than 10 years teaching experience.

\section{Instruments}

The author uses literature study, questionnaire analysis, classroom observation and after-class interview, and sort, analyze, and classify the materials about classroom questioning aspects by reading literature.

\section{Literature Study}

Mainly based on the content and purpose of the study and the full use of the books, the Internet, the library and other resources, this study learns from them and provides the theoretical basis for the study.

\section{Questionnaire}

The author designs questionnaire about the current state of classroom questioning in college English class and chooses 200 English-majored students in four classes of the college to conduct questionnaire surveys. In this study, the questionnaires are designed according to relative questionnaires on classroom questioning combined with the real condition of the research subjects. Totally there are 200 questionnaires for students handed out and 200 valid questionnaires are recollected. Questionnaires were written in Chinese, which can avoid unnecessary misunderstanding. The questionnaire consists of 10 questions to collect information from students with regard to how the classes usually go on, what kind of questions are asked, how questions are distributed, what feedback the teachers provide for students. It mainly includes the following parts: types of questions, distribution of questions, wait-time and teachers' feedback. All the questions are multiple-choice and they are easier to answer and don't take too much time, so the students are willing to answer those questions. In this way, the reliability and validity of the questionnaire can be guaranteed better.

\section{Classroom Observation}

In the case that questionnaire is insufficient to fully reflect the types most widely used by teachers, the author employed classroom observation as supplementary means. During the practice, the author observes more than 200 students and does classroom record correspondingly. In the process of classroom observation, the author records the questioning types, distribution, wait-time, and feedback and so on.

\section{After-Class Interview}

In the study, the author uses spare time to carry out interviews to the teachers mainly about the design of classroom questioning, comments, suggestions and other aspects. In the process of interviewing, the author tries to create a relaxed atmosphere as much as possible. Consequently, the author gains some unexpected information.

\section{Statistical Procedures for Data Collection}

The author had a teaching practice in Shanxi Normal University in September 2016 and then began the classroom observation after the permission from school leaders. The author observed 16 English classes altogether in the four classes. Then the author distributed 200 questionnaires and 200 questionnaires were recollected. The questionnaire is finished in January, 2017. Before students finishing the questionnaire, the author gives them some advice on how to fill the questionnaire. Students are required to finish the questionnaire in 10 minutes. In order to let students do more accurate choice, the questionnaire is made in Chinese.

\section{Data ANALYSIS AND Discussions}

In this chapter, the writer attempts to find out the results of the data collected from classroom observation, student's questionnaires as well as the interview with detailed analysis and discussion from the data collected.

\section{A. The Analysis of Questionnaire}

\section{The Type of Questions}

The first and second questions are aimed at the type of questions and the author draws the following table:

TABLE1

QUESTIONING FORMS

\begin{tabular}{|l|l|l|l|l|}
\hline Question forms & Yes / No & Or & Wh- & How / Why \\
\hline Proportion & $14 \%$ & $3 \%$ & $66 \%$ & $17 \%$ \\
\hline
\end{tabular}


As is shown in Table1, we can see Wh-questions occupy $66 \%$ of the classroom questioning, which keep a great proportion. Yes / No questions take up 14\% and Or questions occupy 3\%, according to what we have talked about before about the classification of questioning, we can know that both of which belong to low level questions. Those questions are easy for students to answer. Because the answers are on the books and students just need to pick out answers from the existent knowledge. By asking those questions, the teacher can check how students mastered the knowledge and teachers can gain feedback information and make some adjustment in teaching to make the class teaching more oriented.

However only $17 \%$ of the questioning is to ask reasons and open questions so that students can think widely beyond the book, and gradually they will form the habit of knowing what and why. Open questions have various answers, which can cause students to think actively and can stimulate their desire and motivation in participating in class, as well as promote the language and emotional communication between teachers and students to achieve better teaching effect. With the new reform of curricula, the traditional models of teaching and studying have been changing. It focuses on the development of open-minded rather than only limited to the book. And based on the constructivist theory, students build up their own knowledge structure in the process of their learning rather than acquire knowledge directly from the teachers and from the book. That is to say, the learners make the answer based on their own experience and understanding.

2. The Distribution of Teachers' Questions

The third, fourth and fifth questions are aimed at the distribution of questioning objects, and the author draws the following table:

TABLE 2

NUMBER OF STUDENTS TO ANSWER QUESTIONS

\begin{tabular}{|l|l|l|l|}
\hline \multicolumn{1}{|c|}{ Time } & None & Twice to three times & More than four times \\
\hline Rank & & & $52 \%$ \\
\hline Top ten & 0 & $35 \%$ & $90 \%$ \\
\hline Outside twenty & $20 \%$ & $13 \%$ & $10 \%$ \\
\hline
\end{tabular}

From the table 2 we can see that 80 percent of students who cannot get the opportunity to answer questions are students with lower grades but 90 percent of students who are able to get more opportunities to answer are students with better grades. So we can come to a conclusion that the opportunities of students answering questions in class are unfair, and that classroom interaction lacks equality. Under such circumstances, those students with lower grades may regard unfair treatment as lack of respect, that teachers do not pay attention to them may make those students lose learning motivation and enthusiasm in participating in English class. Therefore, there is significant meaning when choosing questioning objects and the distribution of tasks. For example, teachers should give various opportunities to different students. In general, teachers can let students with good scores answer some deep and complex questions, while teachers can let students with poor scores answer some easy and simple questions. It can help to create harmonies and effective atmosphere for students to learn and can promote the emotional communication between them.

\section{Waiting Time after Questioning}

The sixth and seventh questions are aimed at the waiting time after questioning, and the results are shown in Table 3:

TABLE 3

WAITING TIME AFTER QUESTIONING

\begin{tabular}{|l|l|l|}
\hline title & Option & result \\
\hline \multirow{4}{*}{ Question 6 } & $\mathrm{A}$ & $8 \%$ \\
\cline { 2 - 3 } & $\mathrm{B}$ & $32 \%$ \\
\cline { 2 - 3 } & $\mathrm{C}$ & $52 \%$ \\
\cline { 2 - 3 } & $\mathrm{D}$ & $16 \%$ \\
\hline \multirow{3}{*}{ Question 7 } & $\mathrm{A}$ & $25 \%$ \\
\cline { 2 - 3 } & $\mathrm{B}$ & $53 \%$ \\
\cline { 2 - 3 } & $\mathrm{C}$ & $22 \%$ \\
\hline
\end{tabular}

As can be seen from the table 3: (1) There are respectively $16 \%$ and $52 \%$ of students believing that teachers have no or little waiting time for them to answer after questioning. (2) $25 \%$ of the students still continue thinking in the process of teachers waiting for answers. But 53\% of the students are replaced by other students. So we can know that when students cannot answer, teachers ask others to answer instead give them some indications. But if students cannot be given enough time to think about questions, how can they reply correctly to satisfy teachers? Although sometimes they really cannot answer, teachers should give them some indications when they cannot answer rather than ask others instead. It may hurt students' self-esteem. If more time be given, they will think actively and can increase their confidence by answering teachers' questions with the help of teachers. And in the process of giving them indications, they can make some interactions through eyes, gestures or words, which can promote their emotional communication.

\section{The Feedback of Teachers' Questions}

The eighth, ninth and tenth questions are aimed at the feedback after students answering questions, and the results are shown in Table 4: 
TABLE 4

TEACHERS' FEEDBACK AFTER STUDENTS ANSWERING QUESTIONS

\begin{tabular}{|l|l|l|}
\hline title & option & result \\
\hline \multirow{4}{*}{ Question 8 } & $\mathrm{A}$ & $65 \%$ \\
\cline { 2 - 3 } & $\mathrm{B}$ & $8 \%$ \\
\cline { 2 - 3 } & $\mathrm{C}$ & $16 \%$ \\
\cline { 2 - 3 } & $\mathrm{D}$ & $11 \%$ \\
\hline \multirow{5}{*}{ Question 9 } & $\mathrm{A}$ & $72 \%$ \\
\cline { 2 - 3 } & $\mathrm{B}$ & $12 \%$ \\
\cline { 2 - 3 } & $\mathrm{C}$ & $10 \%$ \\
\cline { 2 - 3 } & $\mathrm{D}$ & $2 \%$ \\
\cline { 2 - 3 } & $\mathrm{E}$ & $7 \%$ \\
\hline
\end{tabular}

As can be seen from the table 4 the majority of students want teachers to make clear evaluations after answering questions. $60 \%$ students argue that teachers generally give praise in the feedback, while just $2 \%$ students choose D, which indicate that the current high school teachers have been fully aware of the importance of positive classroom feedback and can apply to the actual teaching. The students choosing B, C, E options account for $21 \%, 10 \%$ and $7 \%$ respectively, which shows that although teachers have realized the importance of positive feedback, they are not very clear on how to carry out specific analysis according to specific students and questions. Even though general positive feedback can bring confidence to students, it cannot trigger further thought. On the contrary, if the teacher can give targeted analysis for different students, which can not only allow students to further interact with teachers but also allow students to feel concern from their teachers to encourage them to actively participate in classroom teaching.

\section{B. The Analysis of Class Observation and Interview}

The author observes the total of 4 English classes and interviews teachers and students in free time. The following is the author's analysis.

Firstly, the classroom questioning do not really realize interaction, it just produces false communication aiming to better control the class and enhance students' knowledge. English teachers in college tend to ask yes/no questions, wh-questions and translation questions. Actually, those questions are easy for students to answer. They just need to pick out answers from the existent knowledge. But this kind of communication lacks necessary information gap, which does no good to the real interaction between teachers and students. As a result, students can only say yes or no or only know the fixed knowledge on the book, and they cannot communicate in English smoothly. Students will gradually lose the abilities of thinking. Meanwhile, the students are gradually bored with these books, and will lose the interest in learning and will be unwilling to join in class. On the contrary, referential questions and open questions do not have fixed answers, and students can organize their own language according to their understanding. Although students cannot communicate smoothly, they can try to express themselves in English with the teachers' help, which can develop students' communicative competence and language skills. But according to teachers' interview, they show that almost no one is willing to answer after asking referential questions, because they cannot speak English and at least they can read the answer on the book when display questions asked. Under this circumstance, teachers should communicate more with students and encourage them and help them to improve their spoken English.

Secondly, the opportunities of students answering questions in class are unequal. From class observation, the author finds that students have no interest in teachers' questions and are unwilling to answer voluntarily, so teachers often let all the class reply questions. Sometimes the teachers nominate a student to answer at random. And sometimes the teachers nominate students to answer who sit in the first three rows. Even though sometimes teachers may ask students who sit behind, it just aims to warn those who don't listen to class carefully. According to the interview, teachers explain that the purpose of asking the whole class to answer questions is to better control the class. Because teachers know those students who sit behind and with poor scores are not able to reply the questions they raised, so they usually appoint those sit before and with good scores in order to save time. But it may make some students lose learning motivation and enthusiasm in participating in classroom learning and even does harm to students' mental health.

Thirdly, the teachers always appoint students to answer questions and the wait-time is short, so they have little time to think and can only provide a hasty response. When it comes to referential questions, there will be a relatively longer wait-time. However, it cannot be ignored that teachers always appoint certain student before they raise the questions. In this case, the student lacks time to think and can only provide a hasty response. While other students think they cannot be asked to answer questions and soon relaxed. Some students even do not think at all. But according to the interview, the teachers explain that because of limited class time, if more wait-time is given, the completion of teaching tasks will be affected. In fact, they just take the teaching tasks into consideration but ignore the students' development of thinking ability and the interaction between teachers and students, which does no good to the teaching effect. It is obvious that there is still a lot of work for teachers to do on the wait-time.

Finally, the way of teachers' feedback is simple. According to classroom observation and interview, teachers can provide positive feedback to students' answers, and give simple praise or proper comment, but the feedback from teachers is too simple, sometimes even similar. Most teachers often use "Good" or "Well done" or "All right" generally. Classroom observation and interview show that teachers' positive feedback can make learners get correct understanding and feel confidence, and help to increase their motivation and enthusiasm in learning English. However the fuzzy 
evaluation, such as "Good" or "Well done", cannot help to innovate students' thinking. Instead, that teachers occasionally use participatory and heuristic review is able to receive better interactive effects.

\section{CONCLUSIONS}

\section{A. Findings of the Study}

The paper takes Shanxi Normal University as an example, based on the stimulus-response learning theory and constructivist theory, discussing the existing problems in classroom questioning in college English class by analyzing the current situation of classroom questioning and put forward effective questioning suggestions. After five-month questionnaire, classroom observation and interview, the author gets the main findings about the situation of college English classroom questioning as follows:

(1) There is imbalance between display questions and referential questions. Most of teachers ask more yes or no questions and translation questions, while open questions are fewer. In case teachers always use display questions in teaching, which will restrict students' thinking and reduce their interest in learning English.

(2) Teachers often appoint students with excellent scores to answer questions. The majority of students do not have opportunities to reply. If teachers design question just for those minority of students, the majority of students will be disappointed and lose their enthusiasm to learn English.

(3) When teachers raise a question, they do not leave enough wait-time, especially enough wait-time for referential questions and open questions. Even sometimes teachers appoint a student firstly and then put forward a question, leaving no wait-time for the student to reply. In such cases, the student does not have time to think, which is not conducive for cultivating students' thinking ability.

(4) After students answering questions, teachers do not provide appropriate feedback to students. Most of teachers will give students affirmative evaluation, but participatory evaluation, heuristic correction and critical comments are relatively fewer. Even sometimes some teachers just say "good job, Ok or well-done". The purpose of feedback from teachers is to encourage students and help them establish confidence in learning English. However, such simple evaluation is no use at all but just a waste of word.

\section{B. Limitations of the Study}

Although this study has been seriously and carefully designed and conducted, and has already acquired some achievements and provides some valuable references for the future study, it still has some limitations which should be paid more attention in future study. First of all, the data collected in the study is limited. Only 6 teachers are selected as observed subjects and the teachers and students all come from the same school. The findings of the research could be affected because of the limited number of subjects. Secondly, the obtained data have not been analyzed deeply yet. Many of the conclusions derived from the author's experience and observation, so the paper still needs further investigation.

\section{Suggestions for Further Study}

\section{1) Questioning}

Teachers should ask more referential and open questions, such as how/why questions. The new reform of curricula is trying to develop the students' spirit of active study and exploration. What's more, the new curricula care more about the ways to acquire knowledge and ability development instead of focusing more on the quantity of the transmission of knowledge. Referential questions have no fixed answers, and everyone have different ideas towards the question based on their experience and understanding based on the constructivist theory, so students won't feel worried and embarrassed due to false answer, and they can express themselves freely and will initiative to participate in the class, which will better improve teaching effect.

2) Waiting for an answer

Teachers should provide appropriate wait-time for students to answer. If leave them enough time to think, they will reply properly, which can increase their confidence and enthusiasm in English. In general, teachers tend to give them 1--2 seconds, but if the teacher can lengthen wait-time more than 3 seconds, the nature between teachers and students will be changed from "question type" to the "dialogue", which is beneficial to improve classroom atmosphere and promote the interaction between teachers and students, and then make class teaching more effective.

\section{3) Nominating}

Teachers should give various opportunities to different students. Teachers often tend to appoint students with better grades, so it is not fair for students with lower grades. And these students may regard unfair treatment as lack of respect, may make these students lose learning motivation and enthusiasm in participating in learning English. So teachers should create equal opportunities for students to answer questions as much as possible. For the questions which students are interested in, teachers should let students speak freely, and give the chances to the students thinking inactively to answer the question loudly so as to create relaxed atmosphere, and enable each student to participate in the learning process.

4) Feedback

Teachers should provide appropriate feedback to students' answers. Especially teachers can give targeted analysis for 
different students. Positive feedback can make student feel confident and can arouse students' learning interest. But too simple evaluation such as "Good" or "Well done" does no good to students. Teachers should give detailed evaluation according to different individuals, which can not only allow students to further communicate with teachers but can also allow students to feel concern from their teachers, thus it can encourage them to actively participate in classroom learning.

\section{APPENDIX}

调查问卷

亲爱的同学们:

为了更好的了解大学英语教学的现状, 掌握学生对课堂教师提问的要求和期望, 我们特编写了如下问卷。本次调 查问卷采用不记名形式,调查的试题均没有统一的标准答案, 请同学们结合自己平时在课堂中的表现情况如实回 答下列问题。在此,我们对同学们的大力支持和配合表示忠心的感谢!

1. 你比较喜欢回答英语老师在课堂提出的哪类问题?

A. yes or no 类型的问题 B. or 类型的问题

C. wh- 类型的问题 （如 what, when,where） D. how and why 类型的问题

你更喜欢开放性问题还是封闭性问题?

A. 开放性问题 B. 封闭性问题

3. 你的英语成绩在班里多少名?
A. $1-10$
B. $11-20$
C. 21 名以外

4. 你一节英语课上回答问题几次?

A. 没有 B. 一次 C. 两三次 D. 四次以上(含四次)

5. 如果老师上课很少提问你,你觉得是什么原因?

A. 老师本来就很少提问 B. 老师不重视我 C. 老师不喜欢我

6. 当你问答问题时, 老师是否给你足够的等待时间?

A. 经常 B. 有时 C. 很少 D. 没有等待时间

7. 在老师等待你回答问题的过程中,你会做什么?

A. 独立思考答案 B. 等老师叫其他同学回答 C. 寻求同桌的帮忙

8. 回答问题后你是否希望教师对你的答案做出明确评价?

A. 是 B. 否 C. 有时候 D. 不介意

9. 教师对你的课堂表现做出的反馈是什么?

A. 笼统地予以赞扬

B. 指出你具体取得了哪些成就并予以赞扬"

C. 对你的成就表现出极大的关注和信任,对其价值予以肯定"

D. 根本不关心, 不提出建议"

E. 把你的成就与他人对比, 指出不足, 提出建议"

10. 如果你被提问后无法给出答案,你希望老师怎么做?

A. 老师自己给出答案 B. 让另外一个同学作答

C. 给你提示, 让你继续回答 D. 什么也不做

\section{REFERENCES}

[1] Borich, G.D. ed. (1988). Questioning strategies. Columbus: Merrill.

[2] E.c.Wragg. (1984). Classroom Teaching skills. New York: Nichols Publishing Company.

[3] Gao Yan. (2001). Basic Skills of Modern Teaching. Qingdao: Ocean University of China Press.

[4] Hu Qingqiu. (2004). An Investigation and Analysis of College English Teachers' Questioning Mode. Foreign Language World, 6, 167-169.

[5] Long M H \& Sato C J. (1983). Classroom foreigner talk discourse: Forms and functions of teachers questions. Newbury: Newbury House.

[6] Norton, D.E. (1989). The Effective Teaching of language Arts. New York: Macmillan Publishing Company.

[7] Nuttal, C. (2003). Teaching Reading Skills in Foreign Language. Shanghai: Shanghai Foreign Language Education Press.

[8] Orstein, A. (1990). Strategies for Effective Teaching. New York: Harper \& Row.

[9] Shi Fangliang. (2000). Teaching Theory: Principles, Strategies and Research of Classroom Teaching. Shanghai: Huadong Normal University Press.

[10] Tsui, A.B.M. (1992). A functional description of questions. In M.Coulthard (ed.). London: Routledge.

[11] Wu Xiaojia. (2011). Investigation and Research on the Present Situation of Teachers' Questioning in Junior Middle School. Shanghai: Huadong Normal University Press.

[12] Xu Guanghou. (1997). Classroom teaching techniques. Beijing: Beijing Normal University Press. 
[13] Zheng Xiaoli. (2009). An Investigation into the Questioning of English Class in Senior Middle School. Jilin: Dongbei Normal University Press.

Le Zhang was born in Linfen, China in 1994. She is studying for a master's degree in linguistics from Shanxi Normal University, China.

She is currently a postgraduate in the College of Foreign Languages, Shanxi Normal University, Linfen, China. Her research interests include Foreign Language Teaching and Learning and Pragmatics.

Le Zhang is now an external teacher of the College of communication in Shanxi Normal University. 